\title{
PHYTOHAEMAGGLUTININ'S EFFECT ON NEOSPORA CANINUM ANTIGEN PRODUCTION
}

\author{
Mariana Kikuti', Virgínia Bodelão Richini-Pereira ${ }^{1}$, Rodrigo Costa da Silva ${ }^{1}$, Helio \\ Langoni ${ }^{1}$
}

1 UNESP

Correspondência: Helio Langoni: hlangoni@fmvz.unesp.br

\begin{abstract}
The parasite Neospora caninum affects mainly cattle and dogs. This study aimed to evaluate the effect of phytohaemagglutinin (PHE) in antigen production of $N$. caninum NC-1 strain in gerbils (Meriones unguiculatus) and in vitro. 20 gerbils were used, 10 inoculated intraperitoneally with $1 \times 106$ tachyzoites and 10 with $1 \times 106$ tachyzoites plus $300 \mu \mathrm{L} / \mathrm{mL}$ of PHE. 16 bottles of Vero cell culture were inoculated, 8 with $1.5 \times 105$ tachyzoites and 8 with $1.5 \times 105$ tachyzoites plus $30 \mu \mathrm{L} / \mathrm{mL}$ of PHE. Serology of gerbils was performed on day 0 and before euthanasia. Tachyzoites present in peritoneal fluid and cell culture bottles were quantified by Neubauer chamber and by real-time PCR (qPCR). PHE has not interfered in the production of tachyzoites of $N$. caninum in intraperitoneal inoculated gerbils and the effect of PHE in cell culture had a negative impact, considering the qPCR technique as the gold standard.
\end{abstract}

Key Words: cell culture, gerbil, Neospora caninum

\section{EFEITO DA FITOHEMAGLUTININA NA PRODUÇÃO ANTIGÊNCIA DE NEOSPORA CANINUM}

RESUMO: O parasito Neospora caninum acomete principalmente bovinos e cães. A realização deste estudo teve como objetivo avaliar o efeito da fitohemaglutinina (FHE) na produção de antígenos de $N$. caninum cepa NC-1 em gerbils (Meriones unguiculatus) e in vitro. 20 gerbils foram utilizados, 10 foram inoculados intraperitonealmente com $10^{6}$ taquizoítos e $10 \mathrm{com} 10^{6}$ taquizoítos acrescidos de $300 \mu \mathrm{L} / \mathrm{mL}$ de FHE. 16 garrafas de cultura de células Vero foram inoculadas, $8 \mathrm{com} 1,5 \times 10^{5}$ taquizoítos e $8 \mathrm{com} 1,5 \times 10^{5}$ taquizoítos acrescidos de $30 \mu \mathrm{L} / \mathrm{mL}$ de FHE. Sorologia dos gerbils foi realizada no dia 0 e antes da eutanásia. Taquizoítos presentes no lavado peritoneal e garrafas de cultura de células foram quantificadas em câmara de Neubauer e por PCR em tempo real (qPCR). FHE não interferiu na produção de taquizoítos de $N$. caninum em gerbils inoculados intraperitonealmente e o efeito da FHE em cultura de células teve um impacto negativo, considerando-se a técnica qPCR como o padrão-ouro.

Palavras-chave: cultura celular; gerbil; Neospora caninum 


\section{INTRODUCTION}

The parasite Neospora caninum has been discovered and described in 1984 and 1988, respectively. It mainly affects cattle and dogs, but serologic evidence are described in other species, such as buffalo, nonhuman primates, camels, wild canids and cats, and humans (Barr et al., 1994; Ho et al., 1997; Dubey, 2003; Dubey e Thulliez, 2005; Lobato et al., 2006; McCann et al., 2008; Robert-Gangneux; Klein, 2009; Bouer et al., 2010). Dog, however, plays a major role by being considered as both final and intermediate host of the parasite, which can present itself in three forms: tachyzoites, tissue cysts (in intermediate hosts) and oocysts (eliminated only by the definitive host and sporulated in the environment) (McAllister et al., 1998; Lindsay et al., 1999; Dubey, 2003).

Diagnosis of neosporosis is currently based on serological, molecular methods or isolation of the agent. Regarding serological methods, some of the available options are the indirect immunofluorescence assay (IFA), the direct agglutination test (NAT) and enzyme-linked immunosorbent assay (ELISA) (Björkman e Uggla, 1999). Regarding isolation or bioassay, the gerbils (Meriones unguiculatus) are considered the best experimental models for acute neosporosis, due to its highly susceptibility to infection by the agent, not requiring the use of immunosuppressant's (Lindsay e Dubey, 1989; Gondim et al., 1999; Dubey and Lindsay, 2000; Gondim et al., 2001; Pipano et al., 2002; Ramamoorthy et al., 2005).

Direct agglutination test is traditionally made by inoculation of $N$. caninum in immunosuppressed mice added of sarcoma TG-180 cells to increase the antigen production (Romand et al., 1998), though alternative methods are described, such as antigen production in cell culture (Peckham et al., 1998).

It is speculated that some substances with mitogenic properties may facilitate an increase on production of tachyzoites, such as phytohaemagglutinin (PHE). PHE is a lectin purified from the bean Phaseolus vulgaris with mitogenic properties (Börjeson et al., 1964), commonly used for stimulation of mitosis in leukocytes, lymphocytes and also some microorganisms such as amoebe and acanthamoeba (Agrell, 1966; Agrell, 1967). In this context, the aim of this study was to evaluate phytohemagglitinin's effect on $N$. caninum NC-1 strain in two models of antigen production: in gerbils and in cell culture, for direct agglutination test antigen production without the need of immunosuppressant. Gerbils were used as an alternative model animal of antigen production susceptible to inoculation of $N$. caninum without the interference of any other external substances.

\section{MATERIAL AND METHODS}

Parasites, study design and fluid samples collection

A non-random experimental study was design. The present study was approved in the Ethics Committee of Animal Use of São Paulo State University. The number of animals and culture bottles needed was calculated using the software $\mathrm{G}^{\star}$ Power (Universität Kiel, Germany).

Tachyzoites of $N$. caninum NC-1 were grown in $25 \mathrm{~cm}^{3}$ plastic bottles containing Vero cell line in RPMI 1640 media supplemented with $5 \%$ antibiotic and antimycotic solution (Invitrogen, Cat. n. 15240-096). Twenty gerbils (Meriones unguiculatus) were inoculated, 12 females and 8 males, aged 60 to 90 days. For intraperitoneal inoculation, the tachyzoites were harvested from culture 
bottles, centrifuged at 1,600 $\mathrm{G}$ for 10 minutes and resuspended in sterile phosphate buffered solution $\mathrm{pH}$ 7.2. Concentration of inoculums was 1 $x 10^{6}$ tachyzoites per gerbil, in agreement with previous studies (Gondim et al., 1999; Pipano et al., 2002). PHE (Cultilab) was added to the inoculums of the PHE group animals at the volume of $300 \mu \mathrm{L} / \mathrm{mL}$ suspension of tachyzoites $(150 \mu \mathrm{L}$ per gerbil). All animals were examined daily to detect possible signs of disease. Euthanasia was performed in chamber saturated with isofluorane when animals were suffering from acute neosporosis. All animals had their blood taken via retroorbital sinus through heparinized capillary of $0.9 \mathrm{~mm}$ under general anesthesia with isofluorane at the first day of the experiment and prior to euthanasia to confirm infection via indirect fluorescent antibody test. Serum was obtained by blood centrifugation at $1,600 \mathrm{G}$ for 10 minutes. Peritoneal fluid was obtained immediately after euthanasia of the gerbils by inoculation of $5 \mathrm{~mL}$ of $10 \%$ saline supplemented with antibiotics (penicillin and streptomycin) in the abdominal cavity and recovery using disposable syringe. Peritoneal fluid was immediately counted in Neubauer chamber and centrifuged at 1,600 G for 10 minutes, resuspended in the same initial volume with ultrapure water and stored in microtubes free of DNase and RNase at $-20^{\circ} \mathrm{C}$ for analysis by real time PCR (qPCR).

For inoculation in cell cultures, the parasites obtained from previous cell culture were harvested and directly inoculated in bottles containing confluent monolayer of Vero cell line in a volume of $0.3 \mathrm{~mL}$ of inoculums containing 468,000 tachyzoites per $\mathrm{mL}\left(1,4 \times 10^{5}\right.$ tachyzoites per bottle). PHE was added in the PHE group bottles at the volume of $30 \mu \mathrm{L} / \mathrm{mL}$ of medium in cell culture

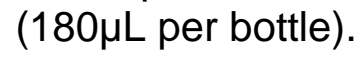

Indirect Fluorescent Antibody Test IFAT

For detection of antibodies anti-N. caninum it was used IFAT (Dubey et al., 1988) at the dilutions $1: 25,1: 50,1: 100$, $1: 200$ and 1:400 with anti-mouse conjugated at 1:100 dilution (Mouse immunoglobulins, DAKO A/S, Denmark, Code No. F0232).

\section{Tachyzoites quantification}

Quantification of tachyzoites was performed by counting in Neubauer chamber and by qPCR (Leon et al., 2012). Genomic DNA was extracted from peritoneal suspensions and cell culture using the DNA extraction kit "Illustra tissue \& cells genomicPrep Mini Spin®” (GE Healthcare, USA) and measured by spectrophotometer (GE Healthcare, USA). All samples were extracted without duplicates, but qPCR of each sample was performed in triplicate. For each reaction it was used a standard curve determined by counting the number of previously cell culture cultivated tachyzoites in Neubauer chamber, in serial dilution, starting from concentration $10^{6}, 10^{5}, 10^{4}$, $10^{3}, 10^{2}, 10^{1}$ and $10^{0}$.

DNA of $N$. caninum was amplified using primers Np6 (5'CAGTCAACCTACGTCTTCT-3') and Np21 (5'-GTGCGTCCAATCCTGTAAC$\left.3^{\prime}\right)$ that amplifies a region of 328 base pairs (bp) (Yamage et al., 1996). Each reaction was performed in a final volume of $25 \mu \mathrm{L}$ containing $12.5 \mu \mathrm{L}$ of Power SYBR $\AA$ Green PCR master Mix (Applied Biosystems, USA), $5 \mu \mathrm{M}$ of each oligonucleotide, $8.5 \mu \mathrm{L}$ of ultrapure water and $2 \mu \mathrm{L}$ of sample. The reactions were performed in StepOnePlus Real-Time PCR System thermocycler (Applied Biosystems, USA), according to the supplier's protocol, using initial denaturation at $95^{\circ} \mathrm{C}$ for 10 minutes followed by 40 cycles of $95^{\circ} \mathrm{C}$ for 15 seconds and $60^{\circ} \mathrm{C}$ for 1 minute, and a final cycle of $95^{\circ} \mathrm{C}$ for 15 seconds. 
Results were viewed and analyzed with the program StepOne ${ }^{\mathrm{TM}}$ Software v2.1.

Neubauer chamber counting was performed using the following formula: number of cells $/ \mathrm{mL}=$ (total number of cells/number of quadrants counted) $x$ dilution factor $\mathrm{x} 10.000$.

\section{Statistical Analysis}

Data were tabulated in an Excel spreadsheet and statistically analyzed in GraphPad Instat® v.3.06. Median, 25\% percentile and $75 \%$ percentiles were determined and compared by nonparametric tests. Concentration of tachyzoites per $\mathrm{mL}$ was compared by nonparametric Wilcoxon test for antigen treated and untreated with PHE when analyzed by the same quantification method, or by nonparametric MannWhitney test comparing the quantification methods by treatment (PHE or control group).

Subsequently,

comparisons between treated or untreated antigen according to the model of antigen production were performed by Wilcoxon test, and by Mann-Whitney test when comparing the models of antigen production to treatment (PHE or control) of the antigen. For all the analysis, it was considered a significance level $(\alpha)$ of $5 \%$.

\section{RESULTS}

Clinical signs usually started from the third day post-inoculation (DPI), and because of the development of acute neosporosis by all animals. Clinical signs consisted of lethargy, poor general condition, ruffed hair, progressive weight loss and lack of eye opening at stimulus.

All gerbils used tested negative for neospora antibodies at the beginning of the experiment and only two animals seroconverted, with titres 25 and 400 (from PHE and from control group, respectively). Out of the 16 peritoneal fluids recovered, exudates volumes ranging from 1 to $3 \mathrm{~mL}$ were present in 12 of them (6 from each group). The mean exudate volume of the animals from PHE group was $1.2 \mathrm{~mL}$ and from control group was $1.6 \mathrm{~mL}$. The median, percentile and $P$ values comparing the two counting techniques are shown in Table 1. When considering the quantification of tachyzoites by Neubauer chamber, statistical difference $(P=0.0104) \quad$ was found regarding treatment with PHE in gerbil inoculation, resulting in a higher concentration of tachyzoites. On the other hand, considering quantification by qPCR, this correlation could not be observed.

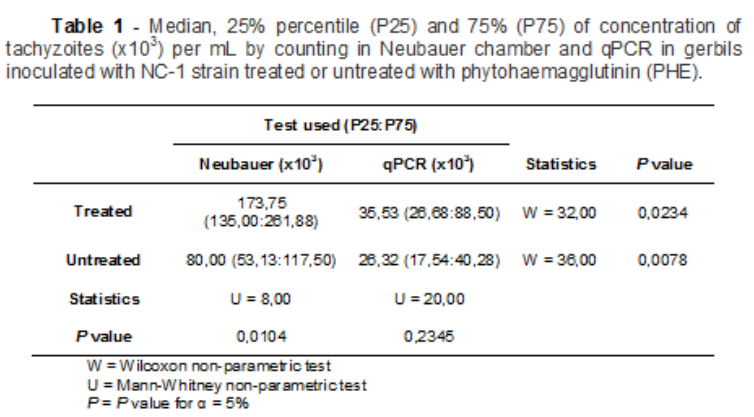

Regarding antigen production in cell cultures, the median, percentile and $P$ values comparing quantification of tachyzoites by Neubauer chamber and qPCR are shown in Table 2. There was no statistical correlation between treatment with PHE and increased tachyzoites production using Neubauer chamber counting technique. When performed by qPCR, the correlation was negative, treatment with PHE decreased production of tachyzoites in cell culture.

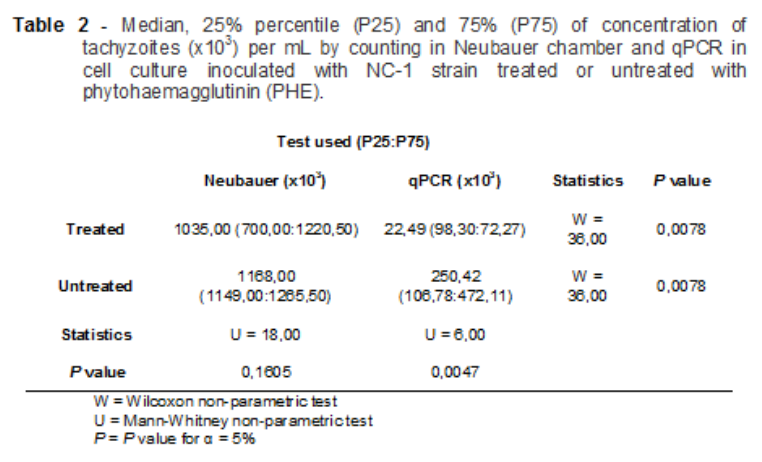




\section{DISCUSSION}

Regarding the disease in gerbils, the clinical signs presented were in agreement with previous studies (Pipano et al., 2002). Infection by $N$. caninum could only be confirmed by IFAT in two animals, a predictable result since presence of antibody is not expected within 5 days of infection.

It was speculated to obtain a higher parasite load, once PHE could increase cell reproduction and, considering an intracellular pathogen, increase $N$. caninum multiplication.

Although the present study had limitations, such as non-randomized allocation of treatment with PHE, it made possible to raise hypothesis on a new possible instrument to increase antigen production of $N$. caninum. Although statistic significant effect was not observed, further studies are necessary to evaluate whether and how treatment with $\mathrm{PHE}$ is influenced by different concentrations. PHE might have a potential to substitute the use of immunosuppressed mice in massive antigen production of $N$. caninum.

\section{CONCLUSION}

In this study, PHE did not increase the production of $N$. caninum tachyzoites regardless of the model used (gerbils or cell culture), though showed a tendency of increasing antigen production in gerbils, which should be further studied with different PHE concentrations. In cell culture, PHE interfered negatively in the production of $N$. caninum tachyzoites.

\section{INFORMATIVE NOTE}

The present study was approved by the Ethics Committee of Animal Use of São Paulo State University under protocol number 146/2010.

\section{REFERENCES}

AGRELL, I.P.S. Phytohaemagglutinin as a mitotic stimulator on free-living amoebae. Experimental Cell Research, v.42, n.2, p.403406, 1966.

AGRELL, I.P.S. The growth of Acanthamoeba and its stimulation by phytohaemagglutinin Experimental Cell Research, v.50, p. 687-692, 1967.

BARR, B.C.; CONRAD, P.A.; SVERLOW, K.W. et al. Experimental fetal and transplacental Neospora infection in the nonhuman primate.

Laboratory Investigation, v.71, n.2, p.236-42, 1994.

BJÖRKMAN, C.; UGGLA, A. Serological diagnosis of Neospora caninum infection. International Journal for Parasitology, v.29, n.10, p.1497-1507, 1999.

BÖRJESON, J.; BOUVENG, R.; GARDELL, S. et al. Purification of the mitosis-stimulating factor from Phaseolus vulgaris. Biochim Biophysa Acta, v.82, n.1, p.159-161, 1964.

BOUER, A.; WERTHER, K.; MACHADO, R.Z. et al. Detection of Anti-Toxoplasma gondii antibodies in experimentally and naturally infected non-human primates by Indirect Fluorescent Assey (IFA) and indirect ELISA.

Revista Brasileira de Parasitologia

Veterinária, v.19, n.1, p.26-31, 2010.

DUBEY, J.P.; CARPENTER, J.L.; SPEER, C.A. et al. Newly recognized fatal protozoan disease of dogs. Journal of the American Veterinary Medical Association, v.192, n.9, p.1269-1285, 1988.

DUBEY, J.P.; LINDSEY, D.S. Gerbils (Meriones unguiculatus) are highly susceptible to oral infection with Neospora caninum oocysts. Parasitology Research, v.86, n.2, p.165-168, 2000.

DUBEY JP. Review of Neospora caninum and neosporosis in animals. Korean Journal of Parasitology, v.1, n.1, p.1-16, 2003.

DUBEY, J.P.; THULLIEZ, P. Prevalence of antibodies to Neospora caninum in wild animals. Journal of Parasitology, v.91, n.5, p.12171218, 2005.

GONDIM, L.F.P.; SAEKI, H.; ONAGA, H. et al. Maintenance of Neospora caninum tachyzoites using Mongolian gerbils (Meriones unguiculatus). New Zealand Veterinary Journal, v.47, n.1, p.36-36, 1999.

GONDIM, L.F.P.; PINHEIRO, A.M.; SANTOS,

P.O.M. et al. Isolation of Neospora caninum from 
the brain of a naturally infected dog, and production of encysted bradyzoites in gerbils. Veterinary Parasitology, v.101, n.1, p.1-7, 2001.

HO, M.S.Y.; BARR, B.C.; TARANTAL, A.F. et al. Detection of Neospora from Tissues of Experimentally Infected Rhesus Macaques by PCR and Specific DNA Probe Hybridization. Journal of Clinical Microbiology, v.35, n 7, p.1740-1745, 1997.

LEON, A.; RICHARD, E.; FORTIER, C. et al. Molecular detection of Coxiella burnetii and Neospora caninum in equine aborted foetuses and neonates. Preventive Veterinary Medicine, v.104, n.1-2, p.179-183, 2012.

LINDSAY, D.S.; DUBEY, J.P. Neospora caninum (Protozoa: Apicomplexa) infections in mice. Journal of Parasitology, v.75, n.5, p.772779, 1989.

LINDSAY, D.S.; DUBEY, J.P.; DUNCAN, R.B. Confirmation that the dog is a definitive host for Neospora caninum. Veterinary Parasitology, v.82, n.4, p.327-333, 1999.

LOBATO, J.; SILVA, D.A.O.; MINEO, T.W.P. et al. Detection of Immunoglobulin $G$ Antibodies to Neospora caninum in Humans: High Seropositivity Rates in Patients Who Are Infected by Human Immunodeficiency Virus or Have Neurological Disorders. Clinical and Vaccine Immunology, v.13, n.1, p.84-89, 2006.

MCALLISTER, M.M.; DUBEY, J.P.; LINDSAY, D.S. et al. Rapid Communication: Dogs are definitive hosts of Neospora caninum.

International Journal for Parasitology, v.28, n.9, p.1473-1479, 1998.

MCCANN, C.M.; VYSE, A.J.; SALMON, R.L. et al. Lack of Serologic Evidence of Neospora caninum in Humans, England. Emerging Infectious Diseases, v.14, n.6, 2008.

PECKHAM, A.E.; SVERLOW, K.W.; CONRAD, P.A. et al. A Modified Agglutination Test for Neospora caninum: Development, Optimization, and Comparison to the Indirect FluorescentAntibody Test and Enzyme-Linked Immunosorbent Assay. Clinical and Diagnostic Laboratory Immunology, v.5, n.4, p. 467-473, 1998.

PIPANO, E.; SHKAP, V.; FISH, L. et al. Susceptibility of Psammomys obesus and Meriones tristrami to tachyzoites of Neospora caninum. Journal of Parasitology, v.88, n.2, p.314-319, 2002.

RAMAMOORTHY, S.; SRIRANGANATHAN, N.; LINDSAY, D.S. Gerbil model of acute neosporosis. Veterinary Parasitology, v.127, p. 111-114, 2005.

ROBERT-GANGNEUX, F.; KLEIN, F. Serologic Screening for Neospora caninum, France.

Emerging Infectious Diseases, v.15, n.6, 2009.

ROMAND, S.; THULLIEZ, P.; DUBEY, J.P.

Direct agglutination test for serologic diagnosis of Neospora caninum infection.

Parasitology Research, v.84, p.50-55, 1998.

YAMAGE, M.; FLECHTNER, O.; GOTTSTEIN, B. Neospora caninum: specific oligonucleotide primers for the detection of brain "cyst" DNA of experimentally infected nude mice by the polymerase chain reaction (PCR). Journal of Parasitology, v.82, n.2, p.272-279, 1996. 